TTR

Traduction, terminologie, rédaction

\title{
Giono, Translator or Reader of Moby-Dick?
}

\section{Isabelle Génin}

Volume 27, numéro 1, 1er semestre 2014

Lecture et traduction

Reading and Translation

URI : https://id.erudit.org/iderudit/1037117ar

DOI : https://doi.org/10.7202/1037117ar

Aller au sommaire du numéro

\section{Éditeur(s)}

Association canadienne de traductologie

\section{ISSN}

0835-8443 (imprimé)

1708-2188 (numérique)

\section{Découvrir la revue}

\section{Citer cet article}

Génin, I. (2014). Giono, Translator or Reader of Moby-Dick? TTR, 27(1), 17-42. https://doi.org/10.7202/1037117ar

\section{Résumé de l'article}

Cet article étudie les rapports entre lecture et traduction dans le contexte de la première traduction intégrale en français de Moby-Dick, traduction réalisée par Jean Giono, Lucien Jacques et Joan Smith, et publiée par Gallimard en 1941. Après avoir dressé un rapide bilan du statut de cette traduction, devenue référence culturelle majeure en France, l'article s'attache au paratexte (le journal, les notes et les lettres laissés par Giono) et aux tapuscrits pour éclairer ce qui semble paradoxal : d'un côté la lecture attentive que Giono fait de Moby-Dick, et de l'autre les stratégies de clarification et de simplification déployées dans la traduction. Quelques analyses stylistiques illustrent les choix de traduction ainsi que le rôle joué par chacun des participants. Il apparaît que Giono n’a pas mal lu Moby-Dick, ni sous-estimé son importance et sa portée, mais plutôt qu'après avoir lu le roman, il s'est désintéressé de sa traduction et a concentré ses efforts sur ses propres oeuvres, ré-investissant dans celles-ci l'expérience de sa lecture. Quant aux autres traducteurs, Joan Smith a proposé une traduction mot à mot qui n'interprète pas le texte tandis que Lucien Jacques s'est efforcé de ré-écrire cette première version littérale malgré le handicap de sa position de non-lecteur (certes enthousiaste) de Moby-Dick.
Ce document est protégé par la loi sur le droit d'auteur. L’utilisation des services d'Érudit (y compris la reproduction) est assujettie à sa politique d'utilisation que vous pouvez consulter en ligne.

https://apropos.erudit.org/fr/usagers/politique-dutilisation/ 


\title{
Giono, Translator or Reader of Moby-Dick?
}

\author{
Isabelle Génin \\ Université Sorbonne Nouvelle - Paris 3
}

\begin{abstract}
The article discusses the interaction between reading and translating, in the case of the first unabridged translation of Moby-Dick into French by Jean Giono, Lucien Jacques and Joan Smith, published by Gallimard in 1941. After a brief survey of the status of that translation - an important cultural landmark in France-the paper examines what the paratext (Giono's diary, notes and letters) and the typescripts reveal about a seemingly paradoxical situation: Giono's keen reading of Moby-Dick on the one hand and the simplification and clarification strategies adopted in the translation on the other hand. A selection of stylistic analyses illustrates both the choices made by the translators and the part played by each participant in the project. It appears that Giono did not necessarily misread Moby-Dick, underestimating its scope and significance. Instead, after reading the novel, he grew indifferent to its translation and concentrated his energy on his own writing in which he re-invested his reading experience. As to the other co-translators, Joan Smith provided a word-for-word translation of the text that made no attempt at interpreting the text, while Lucien Jacques strove to re-write Smith's literal first draft, in spite of his difficult position as a non-reader (albeit an enthusiastic one) of Moby-Dick.
\end{abstract}

Keywords: Moby Dick, French translation, Jean Giono, Lucien Jacques, cotranslation

\section{Résumé}

Cet article étudie les rapports entre lecture et traduction dans le contexte de la première traduction intégrale en français de Moby-Dick, traduction réalisée par Jean Giono, Lucien Jacques et Joan Smith, et publiée par Gallimard en 1941. Après avoir dressé un rapide bilan du statut de cette traduction, devenue référence culturelle majeure en France, l'article s'attache au paratexte (le journal, les notes et les lettres laissés par Giono) et aux tapuscrits pour éclairer ce qui semble paradoxal: d'un côté la lecture attentive que Giono fait de Moby-Dick, et de l'autre les stratégies de clarification et de simplification déployées dans la traduction. Quelques analyses stylistiques illustrent les choix de traduction ainsi que le rôle joué par chacun des participants. Il apparaît que Giono n'a pas mal lu Moby-Dick, ni sous-estimé son importance et sa portée, mais plutôt qu'après avoir lu 
le roman, il s'est désintéressé de sa traduction et a concentré ses efforts sur ses propres œuvres, ré-investissant dans celles-ci l'expérience de sa lecture. Quant aux autres traducteurs, Joan Smith a proposé une traduction mot à mot qui n'interprète pas le texte tandis que Lucien Jacques s'est efforcé de ré-écrire cette première version littérale malgré le handicap de sa position de non-lecteur (certes enthousiaste) de Moby-Dick.

Mots-clés: Moby Dick, traduction française, Jean Giono, Lucien Jacques, co-traduction

The aim of this article is to examine the interaction between reading and translating in the specific context of the "first" French translation of Moby-Dick - the American masterpiece Herman Melville published in 1851. This long and complex novel was unsuccessful when first published in the United States. It was only rediscovered and re-evaluated in the 1920s to become the "great classic" we all know ${ }^{2}$. French readers had to wait until the 1940s to discover an unabridged translation. The French translation of Moby-Dick was published by Gallimard in 1941, with the following acknowledgement: "traduit de l'anglais par Lucien Jacques, Joan Smith et Jean Giono." As in any translation, reading, translating and re-writing were closely linked but at the same time divided between the three co-translators.

Reading is translating and translating is reading, as many theoreticians have stated. This is the view developed for instance by Rainer Schulte in his essay "Translation and Reading" and later in the introduction to his books The Craft of Translation (1989) or Theories of Translation: An Anthology of Essays from Dryden to Derrida (1992), in which Hans-Georg Gadamer is quoted: "Reading is already translation, and translation is translation for the second time [...] The process of translating comprises in its essence the whole secret of human understanding of the world

1. In this article, the title of Melville's novel is hyphenated the way it was in the original American edition: Moby-Dick (hyphen) for the title of the novel and Moby Dick (no hyphen) for the name of the white whale. This is also the editorial choice of the Penguin edition (Melville, 1986), the Norton edition (Melville, 1967) and of the latest French translation by Philippe Jaworski (Melville, 2006). Conversely the 1930 American edition, Giono's translation and Guerne's translation use a non-hyphenated title.

2. The Norton edition (Melville, 1967) gives a good insight into the evolution of Moby-Dick's reception in the US from obscurity to critical acclaim by offering a selection of reviews. 
and of social communication" (cited in Schulte and Biguenet, 1992, p. 9). Reading is a dynamic process which creates sense, all the more so when it is done by a translator, whose reading is necessarily particularly intense, a superior form of reading, as Freddie Plassard explains, "archilecture menée à son terme, dans une assimilation totale du texte qui débouche sur sa 'conversion' en un langage personnel, marque par excellence d'une lecture accomplie dont la traduction est une modalité particulière" (2007, p. 21).

Reading is the first stage, without doubt the most important, as it informs the following stages of the hermeneutic motion defined by George Steiner as "understanding, and the demonstrative statement of understanding which is translation" (cited in Venuti, 2007 [2000], p. 193). In Steiner's view, reading is the moment when the "initiative trust" takes place, conditioning the following three steps: invasion, incorporation and compensation. What is interesting in the case of this particular translation is the fact that the various processes involved were split between the different co-translators, each concentrating on one aspect of the task, one (Joan Smith) reading the text without that first act of trust since she gradually thought the text devoid of a recognizable and consistent meaning, the other two (Lucien Jacques and Jean Giono) interpreting, creating meaning out of the first translator's crib and re-writing it to incorporate it in the French language and culture.

\section{Context: Reception and Status of the Translation}

Although the title page acknowledges three co-translators, the translation is commonly referred to as Giono's translation in academic papers and reviews. This is probably because of the fame and literary credit attached to Giono's name, Giono being one of the major French writers of the $20^{\text {th }}$ century. As such he embodies what Pierre Bourdieu calls the "symbolic capital" of an author, a key notion which Jean-Marc Gouanvic applied to translation studies in his books about translated American novels in France before and after the Second World War: Pratique sociale de la traduction. Le roman réaliste américain dans le champ littéraire français (19201960) (2007) and Sociologie de la traduction. La science-fiction américaine dans l'espace culturel français des années 1950 (1999). 
As to the intrinsic qualities of Giono's translation, opinions differ. Hubert $\mathrm{Nyssen}^{3}$, in 2004, stated it was the best:

Dans les lectures et relectures que je fis alors, l'envie me vint de reprendre Moby Dick d'Herman Melville et de me livrer à une comparaison entre les traductions françaises disponibles. L'une d'elles était de Jean Giono et il ne m'a pas fallu longtemps pour constater, par des retours incessants au «texte source» comme disent les linguistes, qu'elle était de fort loin la plus juste, au sens où on le dit de l'interprétation d'une oeuvre musicale. Juste par le ton de l'histoire et par l'étoffe du texte autant sinon plus que par l'exactitude linguistique. (Nyssen, 2004, p. 1)

On the other hand, Philippe Jaworski, who re-translated MobyDick for the Pléiade in 2006, explained in an interview with the Magazine Littéraire why re-translating the American masterpiece was necessary, thus justifying his re-translation:

Giono avait une connaissance imparfaite de l'anglais et du monde nord-américain. Il a travaillé à partir d'un mot à mot fait par une amie. En outre, je pense que les exigences du traducteur ont changé depuis la fin des années 1930. Aujourd'hui, on s'autorise moins de libertés avec le texte. (Jaworski, 2006, n. p.)

According to Jaworski, the faulty translation by Giono can be explained by the translator's habitus (following Gouanvic's use of Bourdieu's term), his lack of professionalism, namely Giono's inadequate reading of the original text (due to his poor linguistic skills) and the circumstances of the translation process (re-writing a friend's word-for-word translation). The second factor, the changes in the translating norms in France between the 1930s and the early $21^{\text {st }}$ century, is an exterior one. Jaworski too enjoys a high "symbolic capital" since he is one of the most famous Melville scholars in France. His name "guarantees" an adequate reading of the text endowing his translation with a strong sense of legitimacy further reinforced by the authority and prestige of La Pléiade, the collection in which Jaworski's re-translation was published.

3. Hubert Nyssen (1925-2011) was a major literary figure in France. He was a novelist and an influent voice since he was the founder and head of Actes Sud, a renowned publishing house which published Paul Auster and Nancy Huston, among others. 
The reception of Giono's translation has been studied by Michel Gramain in La réception de l'oeuvre de Jean Giono de 1934 à 1944 (2001). He mentions nine reviews in 1941. Not surprisingly the reviews discuss the two authors (Melville and Giono) but little is said about the quality of the translation itself; only vague words of praise are used: "well-translated," "splendid translation."

Giono's translation is also referred to as the first translation of Moby-Dick into French even if in fact two previous texts exist in French. It is, however, the first translation, since the previous texts were not complete translations and had been quite forgotten. A 1928 translation by Marguerite Gay is recorded in the BNF catalogue. It is an abridged work (250 pages, whereas the original is about 700 pages long). Another, older, version is also available but it is a mere summary (25 pages), published in the Revue des Deux Mondes by Émile D. Forgues in February 1853.

It is obvious that Giono had not heard of Marguerite Gay's translation when he started translating, nor had his friend and cotranslator Lucien Jacques. In letter 102 (May-June 1936, Giono, 1983, p. 144), he mentioned it for the first time after discovering it when Gérard Gadiot, a friend of theirs, sent him a copy. Given the interest both men had shown in Moby-Dick in the preceding years and their knowledge of literary publications, we can conclude that Gay's translation was not widely known and had not introduced Melville to the French readership of the time. Indeed, Gay's translation was first published under the title Le Cachalot blanc by Gedalge, a publisher specialised in children's books, thus further blurring the link with Melville's complex masterpiece. This would seem to indicate that both Moby-Dick and Melville were unknown to many French readers except to scholars of British and American literature. This is further corroborated by an article published in Revue anglo-américaine (October 1935), in which we can read that "Melville [...] est encore à peu près inconnu" (p. 115).

If we refer to Antoine Berman's terminology, Giono's translation is indeed a first translation ${ }^{4}$, that is to say published at a time when Melville was virtually unknown to French readers and critics, an introductory translation opening up a new field in the French literary landscape.

4. For further details on Berman's comments on first translations versus retranslations, see Berman (1995, pp. 84-85; 1985, p. 116). 
Jean-Marc Gouanvic, in Pratique sociale de la traduction, signals that American writers were not well-known in France and that things started to change in the 1930s, through the creation of new collections dedicated to foreign literature such as "Du monde entier" in 1931 by Gallimard (2007, p. 90).

When Giono's translation was published by Gallimard it was widely read, as the volume of the sales ${ }^{5}$ and the numerous reeditions $^{6}$ show. It was thus part of the movement that engendered the growing interest of French readers and publishers for American literature in the immediate post-war period. According to Gouanvic, "[1]a logique du marché français de l'édition immédiatement après la Seconde Guerre mondiale est dominée [...] par les écrivains américains" (2007, p. 65). The sudden taste for American authors was also of benefit to Melville, and many of his other novels were translated after Moby-Dick: The Encantadas and Bartleby (1945, trans. Pierre Leyris), Omoo (1947, trans. Olivier Carvin), Mardi (1950, trans. Charles Cestre), The Confidence-Man (1950, trans. Henri Thomas), Benito Cereno (1951, trans. Pierre Leyris), White-Jacket (1951, trans. Charles Cestre \& Armel Guerne), Redburn (1951, trans. Armel Guerne), and Israël Potter (1951, trans. Charles Cestre). A biography of Melville by Pierre Frédérix, Herman Melville, also appeared in 1950. However, neither Jean Giono nor Lucien Jacques played a part in that translation wave; their translation adventure started and ended with Moby-Dick.

Following Giono's translation, three re-translations of MobyDick were published:

(1) Armel Guerne, 1954, Le Sagittaire;

(2) Henriette Guex-Rolle, 1970, Cercle du bibliophile, then Flammarion;

(3) Philippe Jaworski, "La Pléiade”, Gallimard, 2006.

There were also numerous abridged translations for children, the most famous being that by Jean Murray (1954) and Rémi Simon (1982). Marguerite Gay's translation was also re-published under the title Moby Dick in 1954 by Rouge et Or, a publisher specialised in children's books.

5. A NRF note (31 January 1948) indicates 50,500 copies sold by that date.

6. The 1951 edition was the 121 st edition of Moby-Dick, according to the BNF catalogue. 
Nowadays, Giono's translation, regularly re-published by Gallimard, is still the most widely available version in French libraries and bookshops, more particularly in paperback. It has become a well-known work in French literature and, in spite of later re-translations, is still considered the canonical French version of Moby-Dick. The legendary white whale is definitely Giono's "baleine blanche” and not Gay's or Guerne's or Jaworski's "cachalot blanc" 7 . This can be explained by three factors: Giono's fame, the position of symbolic and commercial power held by Gallimard in the French publishing field ("le statut symbolique dominant des éditions Gallimard” (Gouanvic, 2007, p. 56)) and the content of the translation itself. Indeed many changes have been introduced into the translation. Although it looks like an unabridged version, many segments have been omitted and the French text is therefore shorter than the original. The omissions are never conspicuous as they affect some repetitions of words and tend to simplify long sentences (see the examples illustrating this translating strategy in the following part $)^{8}$. The French text concentrates on the sea adventure and offers an extremely enjoyable if simpler read compared to the complexities mentioned by the numerous stylistic studies of Moby-Dick, which is acknowledged to be a bulky, polymorphous and polyphonic novel. This is further evidenced by the fact that Gallimard was able to publish Giono's version first in the NRF collection (serious literature for adults) and later in the "1000 soleils" collection, dedicated to great classics and targeting teenagers.

\section{Giono, a Passionate Reader}

We gain an insight into the type of reader Giono was through a wealth of documents he left (letters, diaries, notes, notebooks, manuscripts). Some of them are still unpublished and kept in Manosque by the Association des Amis de Jean Giono ${ }^{9}$. As part

7. For further details on this point, see Génin (2008).

8. Although a detailed study of Giono's omissions has not yet been published, examples 2 and 3 illustrate the phenomenon. The American version of example 2 contains 62 words whereas Giono's has only 53. In example 3, Melville's text is 50 words long while Giono's has used 32 words. 9. I wish to thank Jacques Mény who is in charge of the Association des Amis de Jean Giono for giving me access to some documents, namely Giono's Carnets, Joan Smith's typed translation of Moby-Dick and a typed draft translation of Moby-Dick by Jacques and Giono. 
of an ongoing research project, this article is based primarily on a limited number of unpublished documents as well as on the following published documents: Giono's diary in Journal, poèmes, essais (1995), the letters he exchanged with his friend, Lucien Jacques, in Correspondance Jean Giono-Lucien Jacques, 1930-1961 (1983), which includes a 5-page text by Jacques about the translation of Moby-Dick, and the numerous notes by Pierre Citron, Henri Godard and Robert Ricatte in La Pléiade's edition of Giono's Complete Works, as well as various interviews. The exact date when Giono started reading Moby-Dick is still subject to debate; it is believed to be somewhere between 1930 and 1935. In an article published in 1962, Katherine Allen Clarke writes "as early as 1930 he was reading the American original with passionate interest" (p. 478), which is confirmed by Giono: "Mais bien avant d'entreprendre ce travail [his translation in 1936], pendant cinq ou six ans au moins, ce livre a été mon compagnon étranger" (1971 [1941], p. 7). However, Lucien Jacques suggests a later date-around 1935-corroborated by Henri Godard in the Pléiade notes on Pour saluer Melville (Giono, 1974b, p. 1106), indicating that Henri Fluchère ${ }^{10}$ lent the novel to Giono in 1935.

Giono read widely and on different occasions he stressed the pleasure he derived from touching and carrying books. In Noé, writing about his imprisonment in 1939 and his solitary confinement, he says: "Je souffrais d'être privé de lecture" (Giono, 1974b, p. 719). In fact, the sense of deprivation he experienced was not because he missed reading stories (he said he spent his moments of confinement making up stories in his head). It was mostly due to the lack of physical contact with books as shown in the anecdote he tells a few pages later. When finally allowed to join the other prisoners in the main unit of the prison he was offered a book by a fellow inmate. Although he could not read the book because it was too dark in his cell and many pages were missing, he described the intense pleasure he derived from simply touching the object:

10. Fluchère (1898-1987), a scholar specializing in English literature and particularly in Shakespeare, was also a translator (T.S. Eliot, H. Miller, ...) and edited or prefaced many books. He was the director of the Maison française d'Oxford (the famous French cultural centre in Oxford) for some years, then professor at Aix-en-Provence University. In 1972 he founded the Association des Amis de Jean Giono with Aline Giono, Giono's daughter. 
Le poids, la forme du livre donnaient à mes mains un plaisir magnifique et très suffisant pour l'instant. [...] je me laissai envahir par le bonheur. Il ne s'agissait pas de lire [...]. Il s'agissait même si peu de lire qu'au bout d'une minute je tins le livre à l'envers et, ainsi tenu, il me donna le plus grand plaisir qu'un livre ait jamais pu me donner (à part Don Quichotte). (Giono, 1974b, p. 721)

That the same physical pleasure was derived from reading or simply touching Moby-Dick is obvious in this remark:

Je l'emportais régulièrement avec moi dans mes courses à travers les collines. [...] il me suffisait de m'asseoir, le dos contre le tronc d'un pin, de sortir de ma poche ce livre qui déjà clapotait pour sentir se gonfler sous moi et autour la vie multiple des mers. (Giono, 1971 [1941], p. 7)

Moby-Dick was his outdoor book which he enjoyed carrying around for two reasons:

(1) the bulk of the volume:

[...] quand je cherche un livre à lire en plein air, en plein champ, je cherche un volume épais, massif, un gros livre. Celui-là était un gros livre [...] qui me plaisait par son format, qui me plaisait par sa forme. (Giono, 1990, p. 262)

(2) pondering the unknown words gave him the time to enjoy the surrounding landscape:

[...] comprenant mal ou assez mal l'anglais, j'éprouvais une certaine difficulté pour le lire. Je rencontrais par exemple des passages de vingt-cinq, trente, quarante, cinquante phrases que je lisais sans être arrêté, puis brusquement, un mot, surtout un mot technique de marine marrêtait. A ce moment-là, j'avais le temps de mâcher et remâcher ce mot extraordinaire, et j'avais le temps à ce moment-là de voir le paysage. Par ce procédé-là, qui est un procédé extrêmement naturel, Moby Dick était pour moi un livre de plein air que je pouvais emporter en promenade. (Giono, 1990, pp. 261-262)

It is obvious though that Giono was fascinated by the novel. He wrote in his diary on June 2, 1936: "C'est un admirable livre américain époque 1850, époque Walt Whitman, de plus de 700 pages sur la mer, le livre le plus étonnant qu'il soit" (Giono, 
1995, p. 127), adding later in an interview: "Et ça a été pour moi une grande découverte quand j'ai découvert Moby Dick" (Clarke, 1959, p. 4).

Reading Moby-Dick was a major experience for Giono: "Moby Dick est un livre qui pendant, disons sept ou huit ans, m'a bouleversé" (Giono, 1990, p. 264). Giono had no personal experience of the sea but found his own work had a lot in common with Melville's novel: "J'ai retrouvé le type même de mon héros dans Melville" (Clarke, 1959, p. 4). He even came to consider Melville as an alter ego he could identify with in Pour saluer Melville $(1941)^{11}$. The emotion he derived from reading MobyDick triggered Giono's decision to translate it and later made him write Pour saluer Melville (1941) and to some extent Fragments d'un Paradis (1948). For Giono the experience of reading the novel was a privilege; and he felt compelled to share the privilege with others, who could not read it in English, first with his friend, Lucien Jacques, then with the readers of Les Cabiers du Contadour, a literary magazine he had created with Lucien Jacques. Eight issues of this publication appeared between the summer of 1936 and the winter of 1939. The decision to translate Moby-Dick was first and foremost an act of friendship and of sharing:

Il me fut très facile de faire partager ma passion pour ce livre à Lucien Jacques. Quelques soirées passées près de mon feu, où tout en fumant nos pipes je lui traduisais maladroitement mais d'enthousiasme certains passages, suffirent à le persuader. Moby-Dick fit désormais partie de notre rêve commun. Il ne nous fallut pas longtemps pour désirer le donner aux rêves des autres. (Giono, 1971 [1941], p. 11)

C'est une chose comme celle-là qu'il faudrait pouvoir donner dans les Cabiers du Contadour. (Giono, 1983, p. 226).

As a reader, Giono was keenly aware of the specificities of Melville's style:

La phrase de Melville est à la fois un torrent, une montagne, une mer [...]. Toujours elle propose une beauté

11. Belghmi documents Giono's interest in Melville and the intertextual relationships between Melville's Moby-Dick, Giono's translation and Giono's Pour saluer Melville (1987, pp. 95-107). 
qui échappe à l'analyse mais frappe avec violence. (Giono, 1971 [1941], p. 12)

In Pour Saluer Melville, a book he published in 1941 as a long preface to his translation of Moby-Dick, he claims that he and his co-translators endeavoured to reproduce Melville's stylistic idiosyncrasies:

Nous nous sommes obstinés à essayer d'en reproduire les profondeurs, les gouffres, les abîmes et les sommets, les éboulis, les forêts, les vallons noirs, les précipices, et la lourde confection du mortier de tout. (Giono, 1971 [1941], p. 12)

The most striking stylistic traits of Moby-Dick can be summarised thus: lengthy periodic sentences, long enumerations, redundancies, numerous adjectives, symmetrical patterns, metaphorical density, complex vocabulary, technical jargon, biblical and Shakespearian mannerisms. In the previous quotation we can see that Giono went so far as to imitate Melville's idiosyncratic enumerations in his own sentence (an object composed of 9 nouns: "les profondeurs, les gouffres, les abîmes et les sommets, les éboulis, les forêts, les vallons noirs, les précipices, et la lourde confection du mortier de tout") as well as his taste for symmetrical and repetitive structures ("abîmes et sommets").

Nevertheless, reading Giono's Moby-Dick is very different from reading the original as it is shorter and simpler, and concentrates on the progression of the sea voyage and Ahab's quest rather than on the digressions of the polyglossic and polymorphic original. Many long circumlocutions mimicking the circumnavigation of the ship and her captain are simplified or reorganised. Many long periodic sentences, whose rhythm is conveyed through repetitions and semi-colons are split into two or three separate sentences. Conversely, shorter sentences are sometimes merged into a longer one, giving a more regular rhythm to the French text than the irregular rhythm of Melville's meandering prose. Inversions and syntactic disruptions are not systematically maintained and the canonical order (subject-verbobject) is often re-established ${ }^{12}$. In the translation, many long noun phrases, with compound words and numerous adjectives are

12. For further details on syntactic reorganisation in various translations of Moby-Dick, see Génin (2002). 
made shorter, omitting what is felt to be redundant, as shown in the following three examples:

Soon they through dim, bewildering mediums, saw her sidelong fading phantom, as in the gaseous Fata Morgana; [...]. (Melville, 1986 [1851], p. 684; my italics)
Alors, à travers les vagues, ils virent son long fantôme s'évanouissant comme dans les brouillards de la fée Morgane! (Melville, 1941, p. 531 ; my italics)

The change here is quite typical of Giono's translation. The vague and polysemic word medium and the two adjectives suggesting the deceptive and confusing quality of the environment are simplified to a simple noun phrase in French, without any adjectives, which merely refers to a very ordinary element devoid of mystery, the waves ("les vagues"). ${ }^{13}$

But wherefore it was that after having repeatedly smelt the sea as a merchant sailor, I should now take it into my head to go on a whaling voyage; this the invisible police officer of the Fates, who has the constant surveillance of me, and secretly dogs me, and influences me in some unaccountable way- he can better answer than anyone else. (Melville, 1986 [1851], p. 97; my italics)
Mais comment se fait-il qu'après avoir maintes fois reniflé l'air comme marin marchand je me suis mis dans la tête de faire un voyage pour pêcher la baleine. L'invisible espion des Parques qui me surveille tout le temps et m'influence mystérieusement peut le dire, lui, mieux que quiconque; [...]. (Melville, 1941, p. 5; my italics)

The English sentence is long and complex, an iconic representation of the difficult questioning it reports. The object comes first ("wherefore [...] voyage"), followed by the anaphoric pronoun this, then comes a long subject ("the invisible [...] way") also followed by a pronoun he. The conclusion of the sentence conveyed in the verb ("can answer") is delayed as the reader must

13. In comparison Armel Guerne's translation reads: "Mais ils ne tardèrent pas à découvrir son long et vague fantôme évanescent, comme dans les fumées de la fée Morgane, à travers les opacités transparentes de la mer agitée" (Melville, 1981 [1954], p. 633). 
decipher first the object and the subject then mentally reassemble the elements to create the meaning of the sentence: "The officer of the Fates can answer wherefore (why) I took into my head to $[\ldots]$." In French, the long sentence has been split into two shorter sentences based on a binary and reassuring pattern: (1) a question; (2) the answer to the question. The redundant phrasing of "who has the constant surveillance of me, and secretly dogs me" has been simplified into "qui me surveille tout le temps" and the indirectness of the quantifier some and the negative prefix of unaccountable replaced by a direct, straightforward word: "mystérieusement."14

[...] I think I can see a little into the springs and motives which being cunningly presented to me under various disguises, induced me to set about performing the part I did, besides cajoling me into the delusion that it was a choice resulting from my own unbiased freewill and discriminating judgement. (Melville, 1986 [1851], p. 98; my italics)
[...] il me semble comprendre vaguement les mobiles et ressorts adroitement cachés qui mont poussé à jouer ce rôle, en me faisant croire que je l'avais choisi de mon propre chef. (Melville, 1941, p.6; my italics)

These two clauses are perfect examples of simplification. ${ }^{15}$ The

14. A. Guerne: "Quant à dire comment il se fit qu'après avoir humé à maintes reprises l'air marin comme matelot long-courrier, je me fusse alors mis en tête d'embarquer pour une campagne de pêche à la baleine, c'est ce que, mieux que quiconque, doit savoir le délégué invisible des Parques qui me tient sans relâche sous sa surveillance, qui m'espionne et me file en secret, et, par des voies inénarrables, m'influence et me gouverne." (Melville, 1981 [1954], p. 62)

15. A. Guerne, in contrast, lengthens here the original by duplicating some noun phrases: "je crois pouvoir [...] apercevoir quelque peu les ressorts secrets et mobiles cachés adroitement sous toutes formes de faux-semblants, de déguisements et de masques, qui mont amené à jouer malgré moi ma partie dans le rôle qui métait dévolu, mais non sans me bercer dans l'illusion trompeuse que c'était par le libre choix de mon seul jugement sans aucun partipris et par la décision sincère et exclusive de mon unique et personnelle volonte" (Melville, 1981 [1954], p. 63; my italics). Guerne's lengthening tendency is harshly criticised by Berman: “Moby Dick 'allongé, d'océanique, devient boursouflé et inutilement titanesque” (1985, p. 71). 
translation takes into account only the core meaning of a segment (cunningly and disguises for the first segment; own freewill for the second segment) and expresses the idea in a much more condensed way, totally alien to Melville's piling up word upon word in his quest for a language capable of translating the world's complexities.

The discrepancy between Giono's claim ("Nous nous sommes obstinés à essayer d'en reproduire les profondeurs [...]" (1971 [1941], p. 12)) and the reality of the style in which the translation was written may be explained in different ways. Although Giono never commented on that particular point, we may surmise that Giono was influenced by the prevailing translation trend of the 1930s-1940s to domesticate foreign texts. Giono probably resorted to clarification and simplification because he did not want Melville's translation to be too far from what he thought French readers were prepared to accept. He consciously or unconsciously adopted the norms of the translated literature of his time. The importance of norms for the translator's strategies and choices have been studied at length by Gidéon Toury in Descriptive Translation Studies and Beyond (1995) and more particularly in his chapter "The Nature and Role of Norms in Translation." Gouanvic signals that the translations of American novels in the 1940s and 1950s in France were mostly target-oriented, domesticating and homogenizing. As stated by Berman, deforming tendencies are stronger when it is a first translation, introducing French readers to an unknown writer and even in the case of American writers to an unknown literature, culture and environment. Giono, who did not mind taking liberties with French stylistic conventions in his own books, was more conservative when it came to translating. It may be because he deemed writing a more creative activity than re-writing someone else's work, however strong his admiration. Itamar Even-Zohar's view of translated literature having "a peripheral position in the literary polysystem" (cited in Venuti, 2007 [2000], p. 200) may indeed be applied to Giono's work. A close look at archival material and at the published paratext gives a clear indication that, although Giono felt strongly moved by his reading of Moby-Dick, his translation activity remained peripheral to his writing career.

\section{Working Conditions}

It is mostly through Lucien Jacques's letters to Giono (Correspondance Jean Giono-Lucien Jacques, 1930-1961) and 
through its Appendix II "La traduction de 'Moby Dick', an undated text by Lucien Jacques, that we can get an idea of how the translation was produced. Lucien Jacques (1891-1961) was Jean Giono's close friend. He was a poet and a graphic artist famed for his woodcuts and engravings. As for Giono, it is worth noticing that his Journal contains only a few lines about his work as a translator. It is as if his translation work did not belong to the diary, dedicated to literary creation.

5 mai 1936: Entrepris avec Lucien Jacques la traduction de Moby Dick pour Quatre Mains. (Giono, 1995, p. 119)

2 juin 1936: Traduction de Moby Dick. C'est un admirable livre américain époque 1850, époque Walt Whitman, de plus de 700 pages sur la mer, le livre le plus étonnant qu'il soit, que j'ai entrepris avec Lucien et Joan Smith de traduire (distraction-emploi des heures où il faut que je quitte Batailles ou autre.) Je crois que cette traduction va faire un bruit considérable. (Giono, 1995, p. 127)

In spite of Giono's statement that he introduced his friend to Moby-Dick: "Il me fut très facile de faire partager ma passion pour ce livre à Lucien Jacques" (Giono, 1971 [1941], p. 11), it seems that Lucien Jacques had been fascinated by the book since 1917, when he had met an American soldier who had talked about the novel. However, Lucien Jacques could not read English and had to wait for a French translation to appear:

Ce nom commençait à m'intriguer, mais je ne voyais toujours rien paraître dans nos bibliographies. Et chaque fois que je devais échanger des points de vue avec un Américain cultivé, je devais entendre parler de Moby Dick. Je pus même feuilleter chez Donald Dewart le livre illustré par Kent. (Giono, 1983, p. 223)

Translating Moby-Dick afforded Lucien Jacques the possibility of reading it: "connaître enfin ce livre qui me poursuivait" (Giono, 1983, p. 226).

Thus a very unlikely team of co-translators was created (with Lucien Jacques supposedly helping Jean Giono to translate although he himself had no English whatsoever). Giono suggested adding a third person to the team, Joan Smith. She was an English friend of theirs who worked in Provence as an antique dealer. The plan was to ask her to supply a word-for-word translation on which 
the two friends, Giono and Jacques, would first work separately, then compare their versions: "demander à Joan Smith de nous faire un mot à mot sur lequel toi et moi ferons une version personnelle sans nous la montrer pour comparer à la fin et fondre nos textes" (Giono, 1983, p. 226). Joan Smith's motivation for participating in the project was twofold: the gratification of having her name associated with that of Giono and the opportunity to make some money as Giono regularly sent her cheques to keep her going.

What emerges from the documents is that Giono's enthusiasm waned rapidly while Lucien Jacques was the person who worked hard so that the project could go ahead. After Joan had translated a hundred pages, which Jacques rephrased, he realised that Giono had done nothing, "pas une ligne" (Giono, 1983, p. 227). The reason was that Giono was now engrossed in his own writing (Batailles dans la montagne and then Le Poids du Ciel) and was no longer prepared to devote many hours to someone else's work. They then decided that Lucien Jacques alone would re-write Joan Smith's text and that Giono would only revise it. He would listen to Lucien Jacques reading his translation aloud while following the original text in the book. Difficulties soon arose. Smith quickly grew tired of Melville's style and Giono hardly ever found the time for revising the text as the sometimes bitter tone of Lucien Jacques's letters shows. Notwithstanding, Lucien Jacques did not give up. On the contrary, he developed a keen interest, "une curiosité de plus en plus vive pour l'œuvre dont j'avais une vraie fringale" (Giono, 1983, p. 227), and was able to work more quickly. In spite of the many difficulties, he managed to have the translation published in four instalments in the last four issues of the Cabiers du Contadour: (1) 23 May 1938: pp.1-120; (2) 5 August 1938: pp.121-240; (3) 13 November 1938: pp. 241400; (4) 31 March 1939: pp. 401-516. These instalments indeed represent the original version of the translation, and not the Gallimard version published in 1941 as commonly assumed.

Giono's revisions seem to have been done quickly according to the letters, most of which were written between instalments 2 and 3. In letter 125 (10 June 1938, Giono, 1983, p. 170) Jacques complains that Giono was not willing to spare the three days necessary to revise the remaining 70 pages due for publication in instalment 2 (which means 20 pages a day). In letter 133 (8 September 1938, Giono, 1983, p. 180) Giono declares that 
he was able to revise 245 pages during a brief period (about two weeks) when both men stayed in Contadour.

Although Lucien Jacques writes admiringly of Giono's role: "Et tout aussitôt du passage mal venu il faisait une phrase incontestable, solide et souple comme une baleinière à la poursuite d'un monstre" (Giono, 1983, p. 228), there is no denying that his participation was a limited one: "Je traduisais sur le mot à mot que Joan Smith, qui est anglaise, et Lucien Jacques, qui est poète, avaient déjà fait! Je remalaxais ces phrases et, généralement, je n'avais pas grand chose à y changer" (Giono, 1990, p. 260). The main co-translators were in fact Joan Smith who read the original and provided a crib, and Lucien Jacques who re-wrote it.

\section{A Six-Handed Work?}

Our comparison of the various versions of Moby-Dick ${ }^{16}$ with the 1930 Random House edition on which the team based their translation is confined to chapter 1 for the purpose of this article. From this study it is clear that Joan Smith did indeed give a wordfor-word translation. She did not interpret the text. Instead, she left its meaning for the other two co-translators to uncover. The following segment is just one example of many passages that remain very obscure in her word-for-word version:

(4)

\begin{tabular}{|l|l|}
\hline American edition: & Smith's typescript: \\
{$[\ldots]$ I am quick to perceive a horror, } & {$[\ldots]$ je suis vite à percevoir une } \\
and could still be social with it- & horreur, et pouvais néanmoins etre \\
would they let me-since it is but & en terms de sociabilite avec lui - me \\
well to be on friendly terms with all & le permettaient-ils-puisque ce n'est \\
the inmates of the place one lodges & que bien d'etre sur termes d'amities \\
in. (Melville, 1930 [1851], p. 8) & avec les habitants de l'endroit ou on \\
& loge. [sic] (my italics, Smith, n.d., \\
& p.9)
\end{tabular}

The many "calque structures" (an expression used by Michel Ballard, meaning structures which are translated literally from the source text and result in incorrect structures in the target text) give the impression that she worked quickly even leaving some

16. The Gallimard version (Gallimard, 1941), The Contadour version (Melville, 1938), Joan Smith's typescript (unpublished), Jacques and Giono's typescript (unpublished). 
words untranslated: "Je suppose that" (Smith, n.d., p. 8). Her French is error-ridden, seeming to indicate poor linguistic skills. However, the vocabulary, and especially the technical vocabulary, is on the whole accurately translated; for instance "vaisseaux, barques, bricks, goelettes" (ibid., p. 5) render "ships, barques, brigs, schooners" (Melville, 1930 [1851], p. 4). At times, a disorientating effect is produced when technical terms are appropriately included in a sentence where the syntax and the translation of the general vocabulary are themselves inadequate.

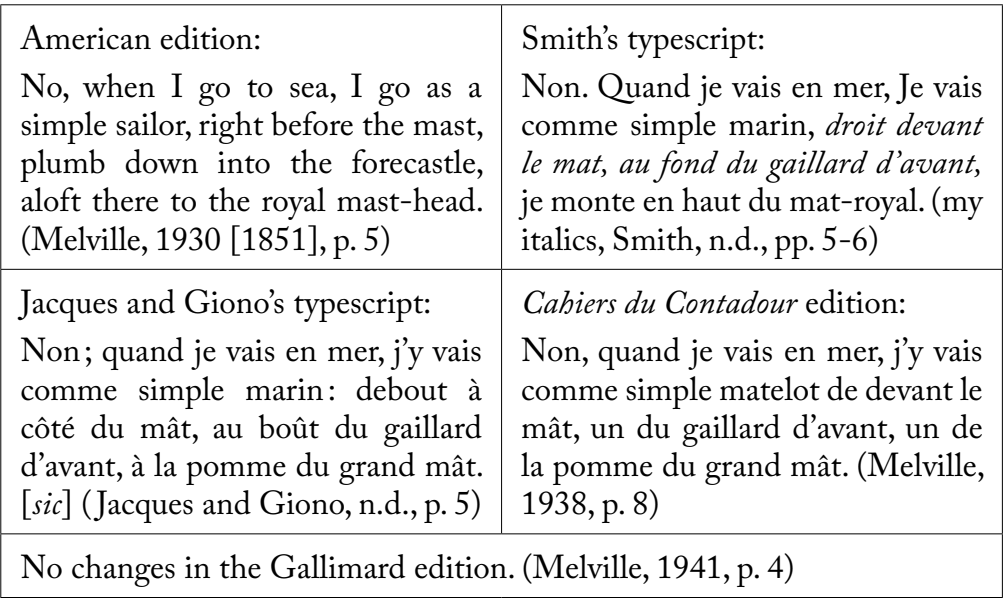

From time to time, Smith made a few comments to help Jacques and Giono find the best words. For instance she suggested Mirages for Loomings, the title of chapter one and added that an older word ("il faut un plus vieux mot") would be better. When translating "upon suddenly receiving two handfuls of silver" by "quand subitement il recevait deux poignees [sic] d'argent" (Smith, n.d., p. 3) she indicated that argent here means the metal and not money ("argent metal"). It is as if she felt her duty was to prepare the translation by carefully translating all the words. Nevertheless, her reading was sometimes faulty as she refrained from interpreting what she was reading - that is making sense of the way the words interact - and was content with giving a word-for-word translation whose meaning had still to be constructed by the other cotranslators. She was sometimes taken aback by the original, which she did not always understand. She added in the margin of the 
complex sentence quoted below: "Cette phrase ne tient pas debout en anglais. Il a du trop en manger" (Smith, n.d., p. 5).

(6)

\begin{tabular}{|c|c|}
\hline $\begin{array}{l}\text { American edition: } \\
\text { It is out of the idolatrous dotings } \\
\text { of the old Egyptians upon broiled } \\
\text { ibis and roasted river horse, that you } \\
\text { see the mummies of those creatures } \\
\text { in their huge bake-houses the } \\
\text { pyramids. (Melville, } 1930 \text { [1851], } \\
\text { p. 4) }\end{array}$ & $\begin{array}{l}\text { Smith's typescript: } \\
\text { C'est des radotages idolatres des } \\
\text { anciens egyptiens au sujet des } \\
\text { ibis grilles et cheval de riviere roti } \\
\text { que vous verrai les momies de ces } \\
\text { creatures dans leurs enormes fours } \\
\text { les pyramids. [sic] (Smith, n.d., } \\
\text { pp. 5-6) }\end{array}$ \\
\hline $\begin{array}{l}\text { Jacques and Giono's typescript: } \\
\text { Et c'est à cause de cette gloire } \\
\text { cuisinière que les anciens Egyptiens, } \\
\text { qui faisaient frire les ibis et rotir les } \\
\text { hippopotames, ont mis les momies } \\
\text { de ces créatures dans les énormes } \\
\text { fours que sont les pyramides. [sic] } \\
\text { (Jacques and Giono, n.d.,p. } 5 \text { ) }\end{array}$ & $\begin{array}{l}\text { Cabiers du Contadour edition: } \\
\text { C'est d'ailleurs à cause d'une manie } \\
\text { culinaire de cette sorte que les } \\
\text { anciens Egyptiens, qui faisaient frire } \\
\text { les ibis et rôtir les hippopotames, } \\
\text { ont mis les momies de ces créatures } \\
\text { dans les énormes fours que sont les } \\
\text { pyramides. (Melville, } 1938, \text { p. } 8 \text { ) }\end{array}$ \\
\hline
\end{tabular}

To create sense, Jacques/Giono had to add the causal link "à cause de." They retrieved the correct French name for "river horse," "hippopotame." As to the translation of "idolatrous dotings," they could not make sense of Smith's proposal and chose a translation based on the co-text they understood (mentioning Egyptians' cooking habits). It would be very interesting to gather more information about the circumstances of the translation of specific segments. Could Jacques, without going back to the original, come up with "qui faisaient frire les ibis et rotir les hippopotames," or is it an example of a change introduced by Giono who had access to the original, even if he was not fluent in English? Did they use a dictionary (in that case it is more likely to be Giono's correction)? Did Jacques ask Smith for more information? The fact that doting was probably not looked up in a dictionary and that river horse is not to be found in most dictionaries may point to the second option. Smith's text is extremely puzzling, it reads like a "calque" translation, like the one Chateaubriand claims to 
have done of Paradise Lost: "J'ai calqué le poème de Milton à la vitre" (Milton, 1836, p. XII), through which the original work can be followed. As a result Smith introduced none of the major omissions, simplifications or reorganisations to be found in the final version of the translation.

The following example illustrates the various stages of the process in a typical sentence.

(7)

American edition:

But here is an artist. He desires to paint you the dreamiest, shadiest, quietest, most enchanting bit of romantic landscape in all the valley of the Saco. What is the chief element he employs? There stand his trees, each with a hollow trunk, as if a hermit and a crucifix were within; and here sleeps his meadow, and there sleep his cattle; and up from yonder cottage goes a sleepy smoke. (Melville, 1930 [1851], p. 3)

Jacques and Giono's typescript:

Tenez! voilà un peintre. Il veut peindre pour vous le paysage le plus romantique, le plus chargé de rêve, d'ombrages, de paix: l'endroit le plus enchanteur de la vallée du Saco. Quelle est sa principale ressource? Il a creusé ses troncs d'arbres comme s'il voulait y abriter un ermite et son crucifix. Il a endormi le pré et son bétail et, de cette ferme, là haut, il a fait monter une fumée paresseuse. (Jacques, n.d., p. 3)
Smith's typescript:

Mais voici un artiste (peintre). Son desir est de peindre pour vous le plus reveur, ombrage, tranquil, enchantant morceau de paysage romanesque dans toute la vallee de the Saco. Quel est l'élément principal qu'il emploie? Voici ses arbres, chacun avec un tronc creux, comme si un hermite et une crucifix taient dedans; et voici dors son pres, et voila dorment son betail; et de ce mas la-haut monte une fumee ensommeille. [sic] (Smith, n.d.,p. 3)

\section{Cahiers du Contadour edition:}

Tenez! voilà un peintre. Il veut peindre pour vous le paysage le plus romantique, le plus chargé de rêve, d'ombrages, de paix: l'endroit le plus enchanteur de la vallée du Saco. Quelle est sa principale ressource? Il a creusé ses troncs d'arbres comme s'il voulait y abriter un ermite et son crucifix. Il a endormi le pré et son bétail et, de cette ferme, là-haut, il a fait monter une fumée paresseuse. (Melville, 1938, p. 7).

No changes in the Gallimard edition. (Melville, 1941, p. 2)

Comparing the various versions of chapter one shows that there are few differences between Jacques and Giono's typescript and the printed versions. It is however difficult to pinpoint what was 
written by Jacques and what belongs to Giono in the typescript we cautiously named "Jacques and Giono's typescript." Although Jacques Mény, who has a great knowledge of Giono's archives, is convinced that it is the work of Lucien Jacques, no evidence has so far been produced to support his view. More genetic research on the Jacques/Giono typescript is needed to shed light on specific segments and give an accurate estimation of the work done by each of them. The whole typescript is composed of three bulky volumes with elements that do not match. For some chapters in volume two, the typescript includes passages with handwritten corrections in the margin and excerpts from a previous draft. Meanwhile, we have to rely on what both co-translators said about their working conditions and conclude that most of the typescript was written by Jacques who, without reading the original, interpreted and re-wrote Joan Smith's "calque" translation. From time to time Jacques/Giono kept Smith's literal translations of some noun phrases, for instance "guetteurs d'eau" (Smith, n.d., p. 1) for "watergazers" or "rêverie océanique" (ibid., p. 2) for "ocean reveries."

The differences between the Contadour version and the typescript are minor, suggesting that the final revision, which was supposed to be Giono's responsibility, was done quickly, Giono changing only a few details. Indeed, as he himself confessed, he had lost interest in the project and let the burden fall on Lucien Jacques's shoulders:

Nous pouvons dire que c'est Lucien qui a fait le plus grand travail! $[\ldots]$ on me reprochait au contraire de n'attacher pas trop d'importance à cette traduction, [...] parce que moi, pendant ce temps-là, j'écrivais d'autres romans [...]. (Giono, 1990, p. 260)

There are also differences between the Contadour first edition and the Gallimard edition of 1941 . The reservations as to who made the changes apply to this second revision too. A letter written by Gaston Gallimard on 12 June 1936 (unpublished) confirms that Jacques contacted Gallimard about the publication of Moby-Dick. In letter 49 to André Gide (9 April 1940), Giono mentions that Lucien Jacques is correcting the proofs of Gallimard's Moby-Dick, sounding rather indifferent to what his friend is doing ("Lucien Jacques vient lui aussi d'être assez sérieusement malade. [...] il est près de moi maintenant, pour quelques jours, en train de corriger les épreuves de Moby Dick" (Gide, 2012, p. 56). 
As far as chapter one is concerned there are not many changes: one segment, omitted in the Contadour version has been added, "quand mon âme est un bruineux et dégoulinant novembre" (Melville, 1941, p. 1); one segment has been corrected: "j'aime les choses terribles" (Melville, 1938, p. 10) vs. "je vois vite l'horreur des choses" (Melville, 1941, p. 6); the creative noun phrase "guetteurs d'eau" has been rephrased through the addition of a relative clause "ceux qui ont envie de l'eau" (ibid., p. 1). The remaining corrections are minor lexical changes and instances of capitalization. The syntactic reorganisation, simplification and clarification have been left unchanged.

Giono's growing indifference to the translation did not mean that he was no longer interested in Melville's Moby-Dick. On the contrary, he published Pour saluer Melville in 1941. The initial motivation for this strange book was to write a preface to the translation of Moby-Dick. However, the preface took on a life of its own, soon developing into a work of fiction in which Giono makes up an imaginary Melville, his fictional alter ego. A few years later, Giono published Fragments d'un paradis (1948). The book reads like Giono's attempt to write his own sea adventures while borrowing heavily from Melville's words and themes in a striking case of intertextual variation ${ }^{17}$.

\section{Conclusion}

Giono's translation of Moby-Dick is an interesting case when questioning the relationship between reading, translating and re-writing. The reading of Moby-Dick was for Giono a decisive experience that confronted him with another literary genius, "un écrivain de la mer" (a writer of the sea), both close to him and far from him, "lécrivain de la terre" (a writer of the land). It triggered a strong desire to translate the novel in an outburst of generosity and friendship. However, the challenges raised by that task discouraged him as they impinged on his own creative work. The demands of the self grew stronger than his initial urge to translate, his "pulsion de traduire," to use Berman's expression, that is to say to open up to the other. In that case the discrepancies we can notice between original and translation are not explained by Giono's misreading Melville, as his comments on his style show,

17. For further details about Melville's influence on Giono's work, see Belghmi (1987). 
but rather by a growing disinterest in that form of interlinguistic translation - which remained peripheral to his writing activitiesand his gradually becoming a non-translator of the text. As he confesses, Moby-Dick remained "comme un livre de lecture" ("a book to be read", Giono, 1990, p. 262) and not a book he felt he had translated.

On the other hand, Lucien Jacques's growing involvement in the translation did not compensate for his awkward situation as a non-reader of the original text. What he worked on was a wordfor-word translation, which was extremely confusing as some of it did not make any sense. Lucien Jacques had to create meaning out of a linguistic maze in which he could not distinguish between what were Melville's complexities and Joan Smith's obscurities.

The fact that this collaborative translation of Moby-Dick was quickly referred to as Giono's Moby-Dick indicates the importance that the translators' "symbolic capital" plays in their visibility. Whereas Smith and Jacques did most of the work, they were not as famous as Giono and gradually became negligible quantities. Giono's literary fame on the other hand endowed the translated text with renewed legitimacy. The translated text was and still is successful partly thanks to Giono's name, which made compensation or restitution possible (the fourth stage of the hermeneutic process involved in translation according to Steiner). The translation, after appropriating the text, has enhanced it by broadening its readership. Its success creates a "positive residue," a notion developed by Steiner: "The motion of transfer and paraphrase enlarges the stature of the original. Historically, in terms of cultural context, of the public it can reach, the latter is left more prestigious" (cited in Venuti, 2007 [2000], p. 196). Giono's Moby-Dick was not seen as a mere translation but as a re-creation by an artist who understood and shared Melville's universe, thus fulfilling the public's yearning for perfect coincidence between a text and its translation. This was reinforced by the publication of Pour saluer Melville which is as much about Giono as about Melville. Giono's interest in Melville's Moby-Dick found other intertextual outlets. He re-appropriated Melville's themes and words within his own books, in a movement of confusion between the self and the other. Although Giono's case is an extreme one, we may also think that to some extent it reveals the complex relationship at the heart of the translation process, especially when 
it has no financial motivation. Translation is closely linked to reading and re-writing, it lies in a pivotal position between two extremes in the chain of intertextual processes. A strong desire to translate can be traced back to the pleasure derived from the act of reading but the motivations are ambiguous and contradictory. It is a selfless move towards the other (the writer being translated and the reader of the translation) as well as a selfish urge to take the other's place.

\section{References}

\section{Primary sources}

Melville, Herman (1930 [1851]). Moby Dick or the Whale. New York, Random House.

Melville, Herman, Harrison Hayford and Hershel Parker, eds. (1967 [1851]). Moby-Dick. New York and London, Norton.

Melville, Herman and Harold Beaver, ed. (1986) [1851]. Moby-Dick; or, the Whale. Harmondsworth, Penguin Books.

\section{Translations}

Melville, Herman (1938). “Moby Dick." Trans. Lucien Jacques, Joan Smith and Jean Giono. Cabiers du Contadour, V, May, pp. 1-120.

Melville, Herman (1941). Moby Dick. Trans. Lucien Jacques, Joan Smith and Jean Giono. Paris, NRF, Gallimard.

Melville, Herman (1965 [1928]). Moby Dick [Le Cachalot blanc]. Trans. Marguerite Gay. Paris, Presses de la Cité.

Melville, Herman (1981 [1954]). Moby Dick. Trans. Armel Guerne. Paris, Presses Pocket.

Melville, Herman (1989 [1941]). Moby Dick. Trans. Lucien Jacques, Joan Smith and Jean Giono. Paris, 1000 soleils, Gallimard.

Melville, Herman (2006). Moby-Dick ou le cachalot. Trans. Philippe Jaworski. Paris, La Pléiade, Gallimard.

\section{Unpublished Typescripts}

Melville, Herman (n.d.). Moby Dick. Trans. Joan Smith. Unpublished.

Melville, Herman (n.d.). Moby Dick. Trans. Lucien Jacques and Jean Giono. Unpublished.

\section{Works Cited}

Anon. (1935). Revue anglo-américaine, October, pp. 115-131.

Ballard, Michel (1995 [1987]). La traduction de l'anglais au français. Paris, Nathan. 
Berman, Antoine (1985). "La traduction et la lettre ou l'auberge du lointain.” In Les tours de Babel. Mauvezin, TER, pp. 31-150.

Berman, Antoine (1995). Pour une critique des traductions: John Donne. Paris, Gallimard.

Belghmi, Michèle (1987). Giono et la mer. Bordeaux, Presses Universitaires de Bordeaux.

Clarke, Katherine Allen (1959). "Interview with Jean Giono.” The French Review, 33, 1, pp. 3-10. [http://www.jstor.org/stable/ 384183].

Clarke, Katherine Allen (1962). "Pour saluer Melville, Jean Giono's Prison Book." The French Review, 35, 5, pp. 478-483. [http://www. jstor.org/stable/383891].

Forgues, Émile D. (1853). "Moby Dick." Revue des Deux Mondes, February, pp. 491-515. [http://www.revuedesdeuxmondes.fr/user/ details.php?code $=65157]$.

Génin, Isabelle (2002). "A careful disorderliness': syntaxe et iconicité de phrase dans Moby-Dick.” Palimpsestes, 14, Paris, Presses de la Sorbonne Nouvelle, pp. 45-54, Textes de référence, Palimpsestes, 14, Paris, Presses de la Sorbonne Nouvelle, pp. 19-25.

Génin, Isabelle (2008). "La Baleine Blanche a mauvais genre." Palimpsestes, 21, Paris, Presses de la Sorbonne Nouvelle, pp. 55-73.

Gide, André and Jean Giono (2012). Correspondance 1929-1940. Revue Giono, hors série.

Giono, Jean (1971 [1941]). Pour saluer Melville. Paris, Gallimard.

Giono, Jean (1972). Euvres romanesques complètes II. Paris, Bibliothèque de La Pléiade, Gallimard.

Giono, Jean (1974a [1948]). Fragments d'un paradis. Paris, Limaginaire, Gallimard.

Giono, Jean (1974b). Euvres romanesques complètes III. Paris, Bibliothèque de La Pléiade, Gallimard.

Giono, Jean and Pierre Citron, ed. (1983). Correspondance Jean GionoLucien Jacques, 1930-1961. Cahiers Giono 3, Paris, Gallimard.

Giono, Jean (1990). Entretiens avec Jean Amrouche et Taos Amrouche. Paris, Gallimard.

Giono, Jean (1995). Journal, poèmes, essais. Paris, Bibliothèque de La Pléiade, Gallimard.

Gramain, Michel (2001). La réception de l'oeuvre de Jean Giono de 1934 à 1944. Villeneuve d'Ascq, Presses Universitaires du Septentrion.

Jaworski, Philippe (2006). "Philippe Jaworski ou Moby Dick en VF." Interview with Béatrice Pire. [http://www.magazine-litteraire. $\mathrm{com} /$ philippe-jaworski-ou-moby-dick-en-vf]. 
Milton, John (1836). Le paradis perdu. Trans. Chateaubriand, Bruxelles, J.P. Meline. [http://books.google.fr/books?id=neg9AAAAcAAJ].

Nyssen, Hubert (2004). Enquête sur trois mille pages de Giono soustraites à l'édition. [http://www.arllfb.be/ebibliotheque/communications/ nyssen100104.pdf].

Plassard, Freddie (2007). Lire pour traduire. Paris, Presses Sorbonne Nouvelle.

Schulte, Rainer and John Biguenet (1989). The Craft of Translation, Chicago, The University of Chicago Press.

Schulte, Rainer and John Biguenet (1992). Theories of Translation: An Anthology of Essays from Dryden to Derrida. Chicago, The University of Chicago Press.

Schulte, Rainer (n.d.). "Translation and Reading.” [http://translation. utdallas.edu/essays/reading_essay1.html].

Steiner, George (1998 [1975]). After Babel: Aspects of Language and Translation. Oxford, Oxford University Press.

Venuti, Lawrence (2007 [2000]). The Translations Studies Reader. London and New York, Routledge.

Isabelle Génin

46 rue de Croisy

02200 Soissons

FRANCE isagenin@club-internet.fr 